\title{
ヒト喉頭粘膜の抗原提示細胞について
}

\author{
石田 春彦，岩 江 信 法，天津 睦 郎
}

\section{Antigen-presenting Cells in Human Laryngeal Mucosa}

\author{
Haruhiko Ishida, M.D., Shigemichi Iwae, M.D., and Mutsuo Amatsu, M.D.
}

Department of Otolaryngology-Head and Neck Surgery, Kobe University School of Medicine, Kobe

Antigen-presenting cells (APCs) are considered to be initiators of the allergic reaction, and Langerhans cells and macrophages are APCs found in the human nasal cavity. We studied the distribution of Langerhans cells and macrophages in human laryngeal mucosa.

Mucosal specimens were obtained from four normal larynxes that were resected due to carcinoma of the mesopharynx or oral cavity. Sections were prepared from the epiglottis, vocal cords, subglottis and the arytenoid portion of the larynx. Langerhans cells and macrophages were investigated immunohistochemically using antibody S-100 protein for the Langerhans cells, CD68 for the macrophages, and the antihuman HLA-DR antibody as an MHC-class II antigen.

Langerhans cells were more abundant than macrophages in the epiglottis and arytenoid portions. In contrast, in the subglottis macrophages were more common than Langerhans cells. Few Langerhans cells or macrophages were seen in the mucosa of the vocal cords. MHC-class II antigens were present in most of the Langerhans cells and macrophages.

These findings suggest that Langerhans cells and macrophages function as APCs in the human larynx. Langerhans cells are present in the squamous epithelium of the larynx, except in the vocal cords, and macrophages are present in the ciliated columnar epithlium.

Key words : ヒト喉頭, ランゲルハンス細胞, マクロファージ, 主要組織適合抗原

\section{I .はじめに}

われわれはこれまで喉頭において I 型アレル ギー反応が起こるかどうかについて，ヒトおよ びモルモット喉頭を用いて，主に肥満細胞に着 目して検討を行ってきた。その結果，七卜喉頭 粘膜では粘膜固有層浅層には粘膜肥満細胞が存 在し，IgE 抗体を有することが証明された ${ }^{1,2)}$ 。 またモルモット喉頭では声門下で肥満細胞が他 の部位より有意に多く存在し，さらに感作モル

神戸大学医学部耳鼻咽喉科学教室

別刷請求： $=650$ 兵庫県神戸市中央区楠町 $7-5-1$ 神戸大学医学部耳鼻咽喉科 石田春彦

投稿受付：1996年 9 月26日
モットの喉頭を抗原に暴露させると, 抗原暴露 直後に灌流液中のヒスタミン濃度が有意に上昇 した ${ }^{3)}$ 。これらの事実より喉頭においてもI 型 アレルギー反応は起こり得るとの結果を得た。

I 型アレルギー反応に扔いても，まず抗原提

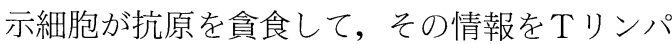
球に伝達することから始まると考えられてい る。現在ヒトの抗原提示細胞は皮膚ではランゲ ルハンス細胞 $(\mathrm{L} \text { 細胞 })^{4)}$, 鼻粘膜ではマクロフ アージ $(\mathrm{M} \phi)^{5)}$ であると考えられている。喉頭 には重層扁平上皮と多列線毛円柱上皮の両者が 存在している。そこで今回われわれはヒト喉頭 粘膜における $\mathrm{L}$ 細胞と $\mathrm{M} \phi$ の存在の有無，およ びその分布について検討した。 


\section{II . 対象および方法}

対象は口腔，中咽頭癌症例で，喉頭摘出を余 儀なくされた 4 例であった。対象症例の年歯は $52 \sim 75$ 歳 (平均年歯60.8歳), 男性 3 例, 女性 1 例であった(表 1 )。いずれの症例も喉頭への腫 瘍の進展はなく，術前放射線治療なども行われ ていない。また 4 症例とも八ウスダストの皮内 テストは陰性であった。

摘出喉頭から直ちに喉頭蓋, 声带, 声門下, 披裂部より組織を採取し，ホルマリン固定を行 い,パラフィン包埋を施した。その後 $5 \mu \mathrm{m}$ の連 続切片を作製した。L細胞に対しては抗ウシ s-100・ウサギポリクローナル抗体 (DAKO), $\mathrm{M} \phi$ に対しては抗ヒトマクロファージ・マウス モノクローナル抗体（DAKO）を用いた。また 主要組織適合抗原 (MHC class II) の発現を検 討する目的で，抗ヒト HLA-DR・マウスモノク ローナル抗体（DAKO）を用いた。2 次抗体以 下は DAKO の LSAB キット（2 次抗体：ビオ チン標識抗ウサギイムノグロブリン・ヤギ抗体
表 1 症例

\begin{tabular}{cccl}
\hline 症例 & 年齢 & 性 & \multicolumn{1}{c}{ 診 断 } \\
\hline 1 & 60 & 女性 & 舌根腫瘍 \\
2 & 75 & 男性 & 舌根腫瘍 \\
3 & 52 & 男性 & 中咽頭腫瘍 \\
4 & 56 & 男性 & 口腔底腫瘍 \\
\hline
\end{tabular}

表 2 抗原提示細胞の分布

( $\mathrm{M}$ ：マクロファージ， L ：ランゲルハンス細胞）

\begin{tabular}{c|c|c|c|c|c|c|c|c|c}
\hline \multicolumn{2}{c|}{} & \multicolumn{2}{|c|}{ 喉頭蓋 } & \multicolumn{2}{|c|}{ 声帯 } & \multicolumn{2}{|c|}{ 披裂部 } & \multicolumn{2}{|c|}{ 声門下 } \\
\cline { 2 - 10 } \multicolumn{2}{c|}{} & M & L & M & L & M & L & M & L \\
\hline \multirow{4}{*}{ 症 } & 1 & + & ++ & + & + & + & ++ & ++ & - \\
\cline { 2 - 10 } & 2 & + & ++ & + & - & + & + & + & - \\
\cline { 2 - 10 } & 3 & + & ++ & - & - & - & ++ & ++ & - \\
\cline { 2 - 10 } & 4 & + & +++ & - & + & + & ++ & ++ & - \\
\hline
\end{tabular}

- : 200倍で検鏡し 0 個

+ : 200倍で検鏡し 2 個末満

$++: 200$ 倍で検鏡し 2 個以上 5 個未満

$+++： 200$ 倍で検鏡し 5 個以上10個未満

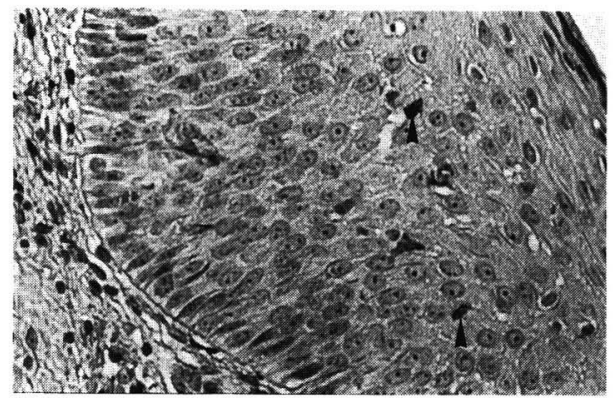

マクロファージ

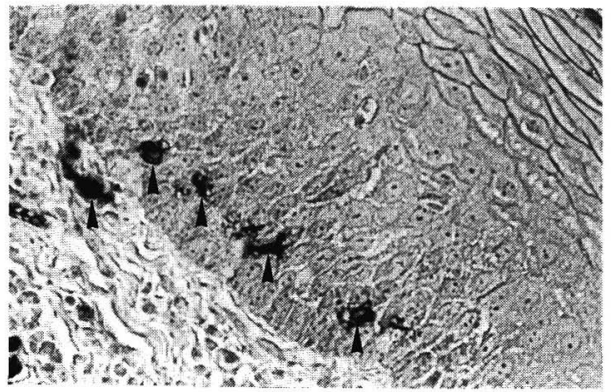

ランゲルハンス細胞

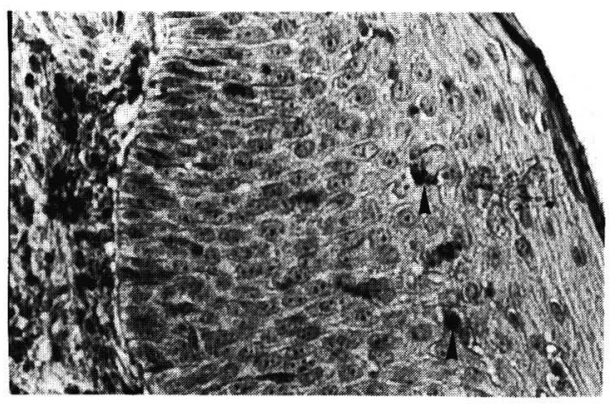

HLA-DR

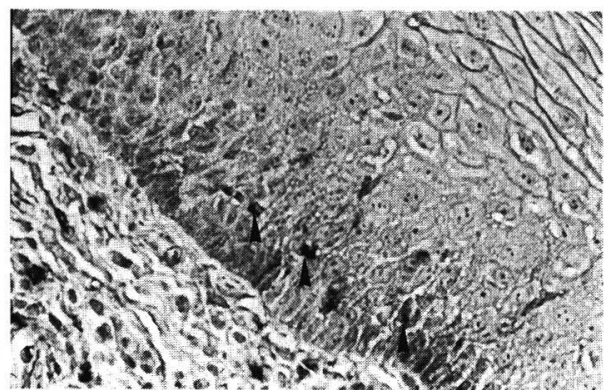

HLA-DR

図 1 喉頭蓋の $\mathrm{M} \phi$ と $\mathrm{L}$ 細胞 $(\times 200)$

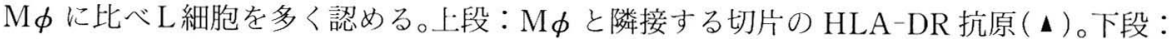

L細胞と隣接する切片の HLA-DR 抗原（ $\boldsymbol{\Delta}$ ）。 


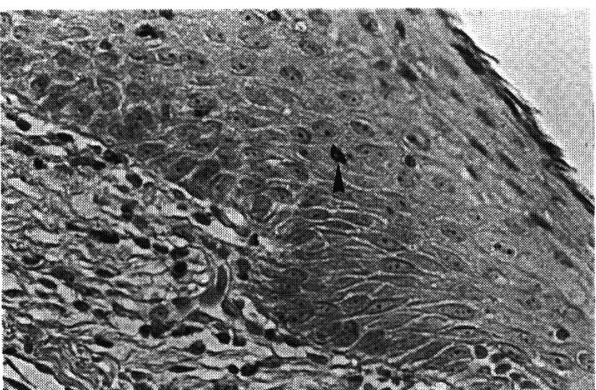

マクロファージ

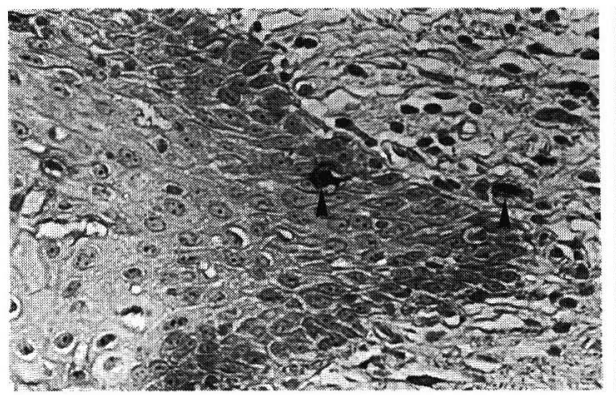

ランゲルハンス細胞

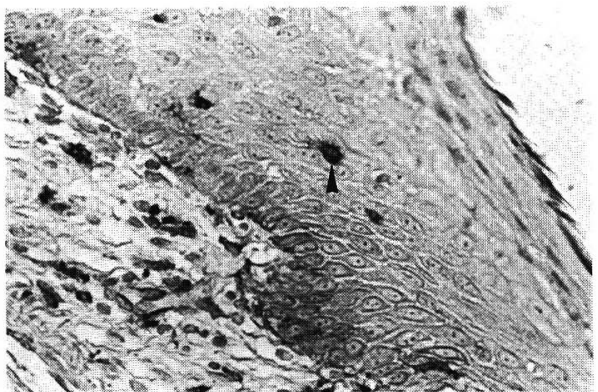

HLA-DR

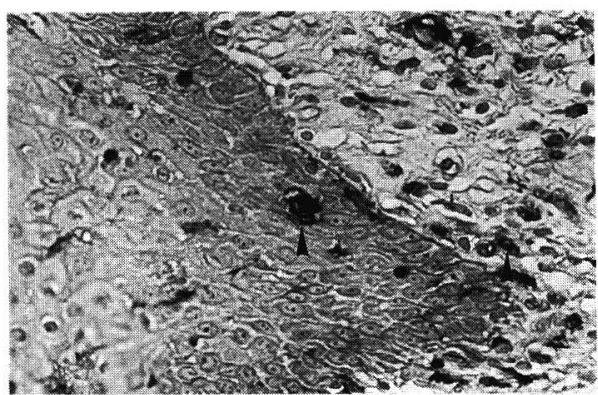

HLA-DR

図 2 声带の $\mathrm{M} \phi$ と $\mathrm{L}$ 細胞 $(\times 200)$

$\mathrm{M} \phi, \mathrm{L}$ 細胞ともに少ない。上段：M申と隣接する切片の HLA-DR 抗原（凶）。下段：L 細胞と隣接する切片の HLA-DR 抗原（ム）。

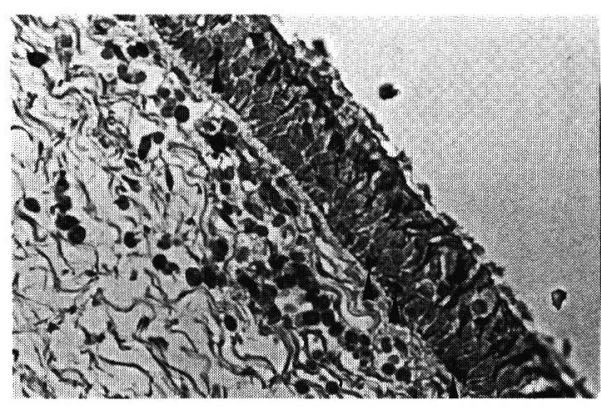

マクロファージ

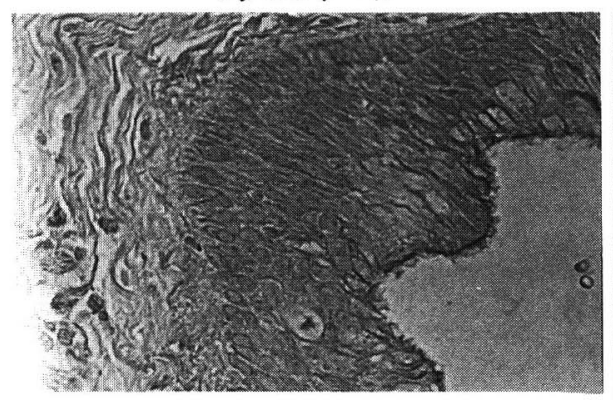

ランゲルハンス細胞

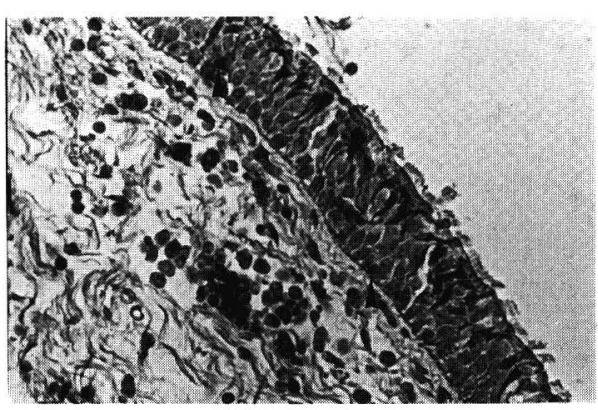

HLA-DR

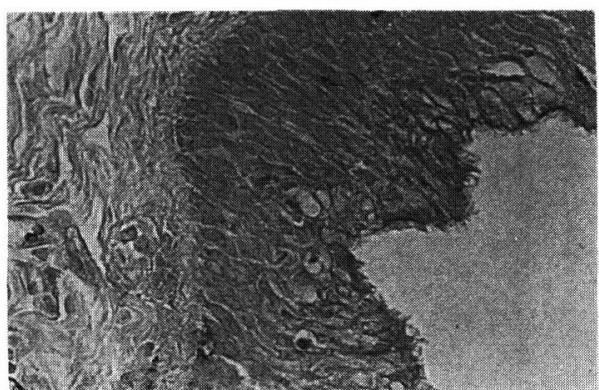

HLA-DR

図 3 声門下の M $\phi$ と L 細胞 $(\times 200)$

L細胞は全く認められない。一方 $\mathrm{M} \phi$ が上皮内に存在していた。上段：M申と隣接する切片の HLA-DR 抗原（山）。下段：L細胞と隣接する切片の HLA-DR 抗原（凶）。 

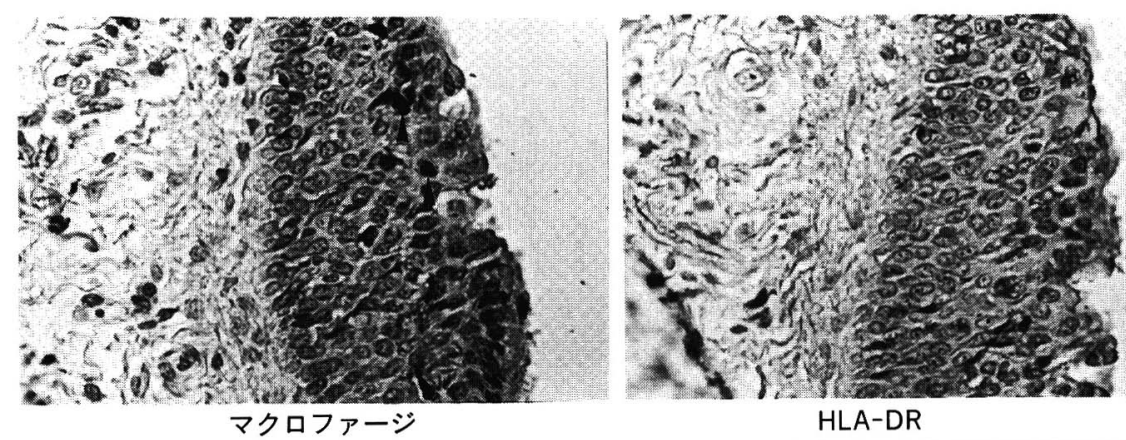

HLA-DR

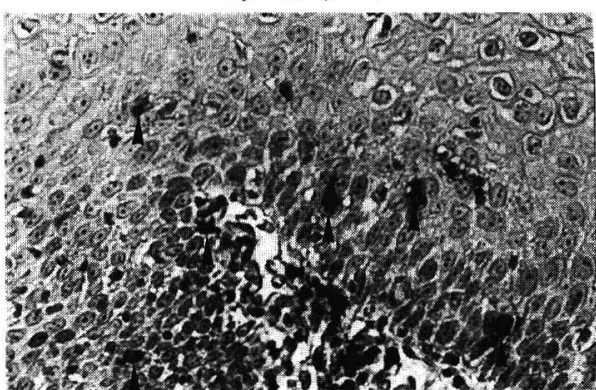

ランゲルハンス細胞

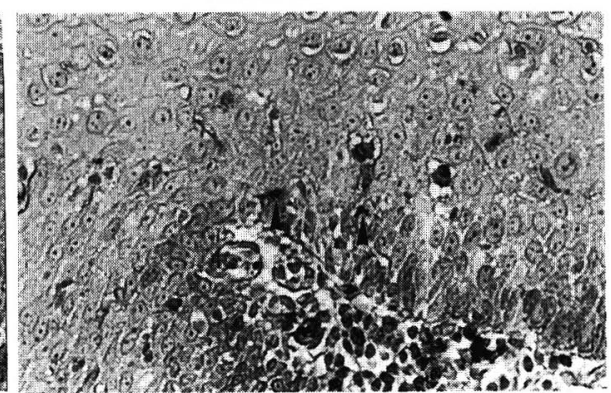

HLA-DR

図 4 披裂部の $\mathrm{M} \phi$ と $\mathrm{L}$ 細胞 $(\times 200)$

$\mathrm{L}$ 細胞を多く認める。上段：M申 と隣接する切片の HLA-DR 抗原 $(\Delta)$ 。下段：L 細胞と 隣接する切片の HLA-DR 抗原 (ム)。

およびビオチン標識抗マウスイムノグロブリ ン・ヤギ抗体, 標識抗体：パーオキシダーゼ標 識ストレプトアビジン, 発色基質 : 3-アミノ-9エチルカルバゾール）を使用した。

\section{III. 結 果 (表 2)}

上記の方法で染色された標本を200倍で検鏡 した。1部位について 5 枚の標本を検鏡した。 また 1 枚の標本内で任意の $3 \sim 4$ 視野を選んで 陽性細胞数を数え, その平均を求めて 1 視野中 の細胞数とした。1 視野に染色された細胞が見 られない場合 $(-), 2$ 個末満の場合 $(+), 2$ 個以上 5 個末満の場合 $(++), 5$ 個以上の場合 $(+++)$ として評価した。

\section{1. 喉頭蓋（図 1)}

喉頭蓋では $\mathrm{L}$ 細胞, $\mathrm{M} \phi$ 両者とも存在してい たが，L細胞は $(++)$ または $(+++)$ であ ったのに対し，M申は 4 症例とも(十)であり, L 細胞のほうがより多数認められた。しかし HLA-DR 抗原は L 細胞, M 現していた。

\section{2. 声帯 (図 2 )}

声带では $\mathrm{L}$ 細胞は 2 症例で $(+)$, 他の 2 症例

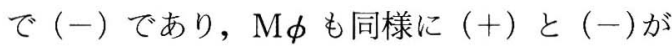
2 症例ずつであった。すなわち声帯では L 細胞, M申ともに少数認められた。いずれも HLADR 抗原は存在していた。

\section{3. 声門下 (図 3 )}

声門下では L 細胞は 4 症例ともに（一）であ ったのに対し，M $\boldsymbol{M}$ は 3 症例で $(++), 1$ 例で (十)であり, 声門下には $\mathrm{M} \phi$ のほうが多く認め られた。また HLA-DR 抗原も認められた。

\section{4. 披裂部 (図 4)}

披裂部では $\mathrm{L}$ 細胞は 3 症例で $(++), 1$ 例で (+) であった。一方 $\mathrm{M} \phi$ は 3 例で $(+), 1$ 例 で（一）であった。つまり披裂部では L 細胞の ほうが多く，喉頭蓋と同様の傾向であった。ま た披裂部でも HLA-DR 抗原の発現が確認され た。

\section{IV. 考 察}

抗原提示細胞は抗原性物質を貪食して, その 
情報を MHC class II 介してTリンパ球に伝 達する。Tリンパ球からは IL-4，5，6が分泌さ れて Bリンパ球の増殖, 分化, 成熟を促し, $\operatorname{IgE}$ 抗体が産生されるようになる。したがって抗原 提示細胞は I 型アレルギー反応に不可欠な細胞 であるということができる。現在のところヒト の抗原提示細胞としては L 細胞など数種類の樹 状細胞と M $\phi$ が考えられている ${ }^{6}$ 。 L 細胞は皮 膚や鼻前庭など重層扁平上皮の存在する部位で 機能しており ${ }^{4,7}$, M $\phi$ は下鼻甲介粘膜など線毛 円柱上皮の存在する部位で機能している5 と考 えられている。

今回われわれは喉頭蓋, 披裂部, 声帯, 声門 下について検討を行ったが，その中で声門下の みが多列線毛円柱上皮であり，他の部位はすべ て重層扁平上皮で被覆されている。これらの部 位に存在する $\mathrm{L}$ 細胞と $\mathrm{M} \phi$ を免疫組織化学的 手法を用いて検討した結果，喉頭蓋抢よび披裂 部にはL 細胞が多く, 声門下では $\mathrm{M} \phi$ が多く観 察された。喉頭においても鼻腔などと同様に重 層扁平上皮の存在する部位では $\mathrm{L}$ 細胞が認めら れ, 円柱線毛上皮の存在する部位では $\mathrm{M} \phi$ が認 められた。

このように上皮細胞の種類によって抗原提示 細胞の種類が異なるということは大変興味深い 所見であり，上皮細胞から何らかのサイトカイ ンが遊離され, それが抗原提示細胞を決定して いるのかもしれない。また L 細胞, $\mathrm{M} \phi$ ともに HLA-DR 抗原を発現していた。このことは喉 頭に存在する $\mathrm{L}$ 細胞, $\mathrm{M} \phi$ が実際に抗原情報を Tリンパ球に伝達している可能性を強く示唆す る所見であると思われる。

一方声帯では，L細胞，M申ともにほとんど 認められなかった。声帯では肥満細胞も非常に 少なく，これらの所見より声帯はアレルギ一反 応が非常に起こりにくい部位であるということ ができる。声門は気道の中でも最も狭い部位で あり，この部位でアレルギー反応が起きれば容 易に呼吸困難を来すであろうと想像できる。し たがって抗原提示細胞, 肥満細胞ともにほとん
ど存在しないということは，生体にとって合目 的な構造であるということができる。

以上のように，七卜喉頭でも声帯以外の部位 では抗原提示細胞が存在し, HLA-DR 抗原も 発現していた。抗原提示細胞から抗原情報を受 け取るリンパ球についても検討する必要はある ものの，この所見はこれまでのわれわれの研究 結果と同様に喉頭においてもIアレルギ一反応 が起こり得ることを示唆するものであると考え る。

\section{V.まとめ}

1）ヒト喉頭における抗原提示細胞について 検討した。

2 ）喉頭蓋，披裂部では L 細胞が多く認めら れた。

3 ) 声門下では M

4 ）声帯には L 細胞，M申ともにほとんど認 められなかった。

5 ) L 細胞, M $\mathrm{M}$ ともに HLA-DR 抗原を発 現していた。

本論文の要旨は第47回日本気管食道科学会総会に おいてロ演した。

\section{文献}

1 ）石田春彦，岩江信法，天津睦郎：ヒ卜喉頭粘膜 の肥満細胞について一非アレルギー症例での検 討一。日気食会報, 46：287-291, 1995 .

2 ) 石田春彦, 岩江信法, 天津睦郎：喉頭に打ける I 型アレルギー反応の基礎的研究.耳鼻， 41 : 860-865, 1995.

3 ) 岩江信法, 石田春彦, 天津睦郎：モルモット喉 頭に抢けるI型アレルギー。喉頭, 7：1-6, 1995.

4) 田中洋一, 吉田彦太郎：樹状細胞. アレルギー の領域, $1: 72-75,1994$.

5 ) 川原孝文, 宮口 衛, 酒井俊一・他：鼻・副鼻 腔病変における樹状細胞とマクロファージの免 疫組織学的研究. 日耳鼻, $97: 240-246,1994$.

6 ）稲葉力ヨ：樹状細胞と免疫応答. 臨床免疫, 1 : 264-283, 1989.

7 ) 吉見龍一郎, 高村博光, 高崎賢治 - 他：鼻粘膜 における抗原提示細胞一第 2 報一. 日耳鼻, 96 ： 1252-1257, 1993. 